London. He was Reader in Malay in the University from 1937 to 1946 and thereafter an Honorary Fellow of the School, and from 1938 to 1959 served on its Governing Body, latterly as representative nominated by the Malayan and Singapore governments.

He joined the Royal Asiatic Society in 1912 and was alternately its Director and President from 1940 to 1964 . Bare facts can do little to invoke the embracing devotion with which he watched over the Society's interests during those often critical years. But two of his undertakings may be mentioned: the mission to secure works of art from India for the memorable Winter Exhibition of 1947 at the Royal Academy, and the part he played in connexion with the XXIII International Congress of Orientalists at Cambridge in 1954. The award to him of the Society's triennial Gold Medal in 1947 was in the circumstances doubly appropriate.

He was the recipient of many other academic and learned distinctions, includingbesides the Oxford degree of D.Litt., to which he proceeded in 1920-the Hon LL.D. of the University of Malaya and honorary membership of the Koninklijk Instituut voor de Taal-, Land-, en Volkenkunde in The Hague, the Koninklijk Bataviaas Genootschap, and the Southeast Asia Institute of the U.S.A. His 85 th birthday was marked by the presentation of a Festschrift volume, Malayan and Indonesian studies (where a full list of his writings will be found), and of special numbers of JRAS and the Bulletin of the School of Oriental and African Studies.

H. L. SHORTo.

\title{
DR. ARTHUR WALEY
}

With the death of Arthur Waley on 27th June, 1966, we have lost one of the greatest of western Orientalists and a scholar of a rare kind. He had been a good classical scholar at Rugby and Cambridge, early in the century, and he is by no means alone in having used such a training as the basis for a career in Orientalism. But it is rather the depth and completeness of his temperamental aptitude for Oriental studies that fill us with a mixed sense of incredulity and gratitude, when we learn, from the 1962 edition of 170 Chinese Poems, how fortuitous was his entry into sinology. This casualness, moreover, to some extent characterizes his subsequent career as an Orientalist, leading him into a greater variety of subjects than is normal in this wide field. He started, as he has told us, as an amateur, in the sense of unprofessional, with the simple motive: "I wanted my friends to share in the pleasure that I was getting from Chinese poetry"; and this desire to share, sometimes with didactic or even admonitory intent, continued to motivate the wholly professional Orientalist that he became. His professionalism came to be based, not on some scholastic speciality nor on the exigencies of an academic appointment-he never held one-but on a mastery of the Chinese and Japanese languages in most of their multifarious varieties. He acquired a fair degree of this mastery with remarkable speed. Within some four or five years of starting, unaided, on his linguistic studies, he had published 170 Chinese Poems (1918) and Japanese Poetry: the Uta (1919). It is significant of his own fearless approach to his work that in the latter book he included some notes on Japanese grammar, on the assumption that other people, with such help, would be enabled to read some uta as easily as he had come to do. 
During this period of his life, Waley was employed in the Print Room of the British Museum, dealing with Chinese and Japanese paintings and prints. It is to this activity that we are indebted for his self-instruction in the languages, and it also resulted in a number of articles, mostly published in the Burlington Magazine and concerned with Chinese painting. But it can hardly be too much emphasized that Waley was essentially a literary person, one whose feelings were generally fed by and mediated through language, and his visual reactions were not particularly acute. He was also working privately at this time on translations from the Japanese, above all that of the Genii Monogatari, the first part of which appeared in 1925 and which was completed in 1933, three years after he had left the Museum. At this point his interest in Japanese literature seems to have faded, but his knowledge of that language was, as most Western sinologues would agree, essential to his subsequent work on the Chinese classics.

A series of four works in this field now began to appear, starting with The Way And Its Power (1934), a study and an attempt at a literal translation of the Tao Te Ching, followed by The Book of Songs (1937; i.e. the Shih Ching), The Analects of Confucius (1938), and Three Ways of Thought in Ancient China (1939), which consists chiefly of extracts from Chuang Tzu, Mencius and Han Fei Tzu. These productions are characteristic of Waley in his more didactic spirit. He thought the general English reading public should at least be given the chance to learn something of the philosophies and literature that had helped to shape the extraordinary civilization of China. His concern for the ordinary reader is explicit, and it even evokes something of an apology for what he considered a certain aridity in his work on the Analects: "I would not have it supposed that I have definitely abandoned literature for learning, or forgotten the claims of the ordinary reader. My next book . . . will be wholly devoid of technicalities ...."

At this point in Waley's career we may pause to look at what he has done and how he has done it. We are surely struck by the combination of confidence, lucidity, and grace with which he has served the "ordinary reader". On the one hand, in The Tale of Genji, he has given us, of a rather difficult text, an English version to which the original has been compared, by at least one authority, unfavourably; on the other, he has presented versions of such classics as the Tao Te Ching or the Lun Yü, stripped as never before, even in the east, of the verbose, mythologizing, theologizing accretions which grow upon them. That there are those who disagree with him in this latter field is natural, inevitable. But we must admire the intellectual independence, itself dependent on a remarkable linguistic intuition, that rendered this work possible at that time. And we must avoid being like certain critics of Wilhelm's version of the Book of Changes, who, according to Waley, "condemned it, most unfairly in my opinion, because it fails to do what in fact the author never had any intention of doing". Sinologues must also acknowledge the penetration of this "free-lance" worker in his early insistence on the indispensability of a running knowledge of all pre-Han literature. With his exceptional linguistic feeling (not confined to Oriental languages), Waley acquired this knowledge with unusually little pain. And it was this feeling and knowledge, underlying all his work, that led him far and wide rather than deep. But of this he was equably, sometimes ironically, aware. In the preface to The Opium War Through Chinese Eyes (1958), he wrote, "I write chiefly for the general reader. But specialists seem sometimes to read my books as a recreation, and for their benefit I have given references ... 
in the hope that they will check up on some of my translations and tell me of my mistakes." If this quotation suggests indulgence in a kind of odium theologicum, it is misleading. Waley was fully aware of what he was "up to" and of what specialists are "up to"; and he acknowledges frequently and generously the help of specialists, as many of them acknowledge his. He was equipped for his work as a scholar with a superb literary memory and an unusually complete linguistic mastery; but he lacked one common characteristic of a scholar, the desire to say the "last word" on a topic-often, indeed, he was inclined to risk saying the first.

What was his success? Short of the dubiety of the "best-seller" but well beyond the succés d'estime of a coterie. Opinions and tastes differ greatly about the merit of his translations from Chinese poets, though all admit that he was an innovator; someone said that he had done more harm to English poetry than anyone else, and T. S. Eliot said that he was no poet. But such judgements are a kind of de facto recognition of power; and no one will deny that his prose translations, except when deliberately literal, are wonderfully free from "translationese". As for the later books, if anyone in England or the United States feels that he knows something about life in China in the time of the poets Li Po, Po Chu-i, and Yuan Mei, if he has reached at least some degree of detachment about the Opium War or the activities of Stein and Pelliot at Tun-huang, some degree of understanding of the rigour rather than the vagueness of Indian and Chinese Buddhist logic, this person probably owes much to Waley. And there are certainly sinologues in various countries who have fruitfully taken up, as specialists, ideas thrown out by Waley.

I knew him only during the last ten years of his life. I would like to recall here one of a number of memories of his calm absorption in his studies. He came to stay with me for a few weeks in the late spring of 1958, when he was working on the texts for Ballads and Stories from Tun-huang (1960). He would sit out in the garden, equipped only with text and necessary stationery; and in the evenings he would share with us, reading aloud, a lot of material that had lain a few hours earlier buried in quite a difficult and often defective Chinese text. He carried his learning lightly with neither arrogance nor false modesty; and he held it always at the disposal of his juniors in the field with no trace either of impatience or of condescension.

Arthur David Waley was born in 1889 , and was educated at Rugby and at King's College, Cambridge. He was created C.B.E. in 1952, awarded the Queen's Medal for Poetry in 1953, and made a Companion of Honour in 1956. He was a Fellow of the British Academy, an honorary fellow of King's College, Cambridge, and of the School of Oriental and African Studies, and held honorary degrees at the universities of Aberdeen and Oxford.

WALTER ROBINSON.

\section{DR. REUBEN LEVY}

Reuben Levy was born in Manchester in April, 1891, and died in Cambridge in September, 1966.

The first and only Professor of Persian in Cambridge (the personal title was conferred upon him in 1949), Levy served his country in the armed forces in both wars, and thus gained 